\title{
Marrow Erythroid and Neutrophil Cellularity in the Dog
}

\author{
Kurt A. Deubelbeiss, John T. Dancey, Laurence A. Harker, \\ Barbara Cheney, and Clement A. Finch \\ From the Division of Hematology, Department of Medicine, University of \\ Washington School of Medicine, Seattle, Washington 98195
}

A B S T R A C T This paper describes a method for determining the number of marrow erythroid and neutrophil cells in which the cellularity of marrow sections was related to that of the total marrow by radioiron dilution. Tissue sections were prepared from methacrylateembedded dog marrow biopsies, and neutrophils were identified by staining of their primary granules. After correction of direct section counts for multiple counting error, accurate neutrophil-erythroid ratios were established with a coefficient of variation of less than $10 \%$ when $10^{4}$ cells were examined. An average neutrophil-erythroid ratio of 1.2 was found in six normal dogs.

The total number of nucleated red cells in the dog was $5.48 \pm 0.78 \times 10^{\circ} / \mathrm{kg}( \pm 1 \mathrm{SD})$, and the corresponding erythron iron turnover was $0.90 \pm 0.11 \mathrm{mg} \mathrm{Fe} / 100$ $\mathrm{ml}$ whole blood/day. The total number of marrow neutrophils, derived from the neutrophil-erythroid ratio, was $6.6 \pm 0.59 \times 10^{9}$ cells $/ \mathrm{kg}$, of which 1.4 were promyelocytes and myelocytes, 2.3 were metamyelocytes and bands, and 3.0 were segmented neutrophils.

Leukopheresis studies were carried out in six dogs to confirm the accuracy of these cellular measurements. Marrow counts showed a mean decrease of $22.7 \times 10^{\circ}$ cells or $35 \%$ of the postmitotic neutrophil pool, and it was calculated that $10.2 \times 10^{\circ}$ additional cells had been taken from already circulating blood. This estimated deficit of $32.9 \times 10^{\circ}$ was almost identical to the $33 \times$ $10^{\circ}$ cells actually counted in the removed blood.

Dr. Harker is an Established Investigator of the American Heart Association. Drs. Deubelbeiss and Dancey were recipients of fellowship stipends from (respectively) the Swiss National Foundation and the Medical Research Council of Canada.

Dr. Deubelbeiss's present address: Division of Hematology, Inselspital, Bern, Switzerland. Dr. Dancey's present address: Division of Hematology, Montreal General Hospital, Quebec, Canada. B. Cheney is with the Letterman Army Institute of Research, Presidio, San Francisco.

Received for publication 21 May 1974 and in revised form 22 November 1974.

\section{INTRODUCTION}

Early estimates of marrow cellularity were based on the volume of active marrow and the relative concentrations of myeloid and erythroid components $(1,2)$. More recent estimates of hematopoietic mass have been based on isotope dilution techniques $(3,4)$. In this study the number of marrow neutrophils in the dog was quantified by relating the number of cells in marrow sections to total marrow cellularity through radioiron labeling. The validity of the method was evaluated in animals whose neutrophilic stores were depleted by leukopheresis.

\section{METHODS}

Six mongrel dogs, weighing $10-12 \mathrm{~kg}$, immunized against canine distemper, and treated for parasites, were studied after an observation period of at least $3 \mathrm{wk}$. These animals had hematocrits over $40 \%$ and neutrophil counts ranging between 3,800 and $10,200 / \mu 1$ during the observation period. On the first day of the study, each animal's plasma iron turnover (PIT) ${ }^{1}$ was measured to establish the relationship between erythroid marrow cellularity and PIT (3-6). On the next day the marrow was labeled by a large intravenous dose of radioiron, and on the third day a marrow biopsy was performed for the determination of cell specific activity. The animal was then sacrificed and the skeleton isolated for direct counting of total marrow activity.

PIT was performed according to established techniques (5). $5 \mu \mathrm{Ci}$ of ${ }^{59} \mathrm{Fe}$ citrate (molar ratio $\mathrm{Fe} /$ citrate $<1: 30$ ) was added to $5 \mathrm{ml}$ of heparinized plasma from an iron-deficient animal and incubated for $15 \mathrm{~min}$ at room temperature on a rotating turntable to permit complete binding with transferrin. After removal of a standard, the remainder was injected through the foreleg vein. Eight $1-\mathrm{ml}$ plasma samples were obtained during the following $2 \mathrm{~h}$. The PIT, expressed as $\mathrm{mg} \mathrm{Fe} / 100 \mathrm{ml}$ whole blood/day was calculated

\footnotetext{
${ }^{1}$ Abbreviations used in this paper: $\mathrm{ACD}$, acid citrate dextrose; $\mathrm{DF}^{32} \mathrm{P},\left[{ }^{32} \mathrm{P}\right]$ diisopropylphosphofluoridate; EIT, erythron iron turnover; $\mathrm{G} / \mathrm{E}$, granulocyte-erythroid; $\mathrm{M} / \mathrm{E}$, myeloid-erythroid; $\mathrm{N} / \mathrm{E}$, neutrophil-erythroid; $\mathrm{NRBC}$, nucleated red blood cells; PIT, plasma iron turnover; PMN, postmitotic neutrophil.
} 
as previously described (5) according to the formula:

$$
\text { PIT }=\frac{\text { Serum iron }}{t_{\frac{1}{2}}(\min )} \times \frac{100-(\text { Hct } \cdot 0.9)}{100}
$$

The erythron iron turnover (EIT) was then derived from the PIT (6) by subtracting the nonerythroid fraction as in the following formula:2

$$
\begin{aligned}
\mathrm{EIT}=\mathrm{PIT}-(\text { Serum iron }[\mu \mathrm{g} / 100 \mathrm{ml}] \\
\\
\quad \times \text { plasmatocrit } \times 0.0035)
\end{aligned}
$$

Erythroid cells of the marrow were labeled by injecting intravenously over a $15-\mathrm{min}$ period $1.5 \mathrm{mCi}{ }^{50} \mathrm{Fe}$ citrate (sp act of $10-15 \mathrm{mCi} / \mathrm{mg}$, molar ratio $\mathrm{Fe} /$ citrate $<1: 30$ ). $18 \mathrm{~h}$ later when the radioiron was maximally localized in the erythroid precursors, a marrow biopsy was obtained from the posterior iliac crest with an electrical drill (Synthes AG., Waldenburg, Switzerland). Marrow was also aspirated from the opposite iliac crest, smeared, and stained by Wright's method. Neutrophil-erythroid (N/E) ratios were determined in smears by counting at least 5,000 cells by using conventional morphologic criteria. The animal was then sacrificed and the skeleton separated and cleaned.

Bone marrow biopsy cores measuring $4 \mathrm{~mm}$ in diameter and $15 \mathrm{~mm}$ in length were fixed in $7.5 \%$ formalin buffered with $0.05 \mathrm{M}$ Sörensen's phosphate buffer at $\mathrm{pH} 7.4$ for $24 \mathrm{~h}$ at $37^{\circ} \mathrm{C}$ and washed with $0.88 \mathrm{M}$ sucrose containing $1 \%$ gum acacia (7). Without decalcification the specimens were progressively dehydrated for 2 -h periods in 50, 70, 85, 95, and $100 \%$ ethanol. For embedding, a modification of the methacrylate technique of Zambernard, Block, Vatter, and Trenner (8) was employed. The cores were placed in methacrylate monomer (Polysciences, Inc., Warrington, Pa.) for two 1-h periods followed by an 8 -h immersion in a 1:1 mixture of methacrylate monomer and embedding medium. ${ }^{3}$ The specimens were then put into fresh embedding medium for $8 \mathrm{~h}$ under vacuum. Finally, they were placed into plastic molds and polymerization was initiated by UV light. Sections were cut at $3 \mu \mathrm{m}$ using a Leitz L 1212 Minot rotary mircotome and steel knives (Leitz O.N., 530 165, wedge-shaped with plane edge, E. Leitz, Inc., Rockleigh, N. J.) and then mounted on albumin-subbed slides. After removal of the plastic by a 15 -min exposure to acetone, the sections were brought to water and incubated for two $45-\mathrm{min}$ intervals at $37^{\circ} \mathrm{C}$ with an incubation medium containing napthol-ASD chloroacetate and diazotized pararosaniline.

2 The detailed mathematical analysis of serum activity in man from which the EIT calculation is derived has not been carried out in dogs; however, there are sufficient studies to indicate a similar plasma radioiron disappearance curve with three major components and other evidence such as an inverse relationship between plasma iron and red cell utilization of radioiron to support the importance of the plasma iron level in determining the amount of iron going to nonerythroid sources. The dog also has the same red cell life span as man, so that kinetics are, in general, quite similar. The calculation, however, is not considered valid in the presence of iron deficiency.

$3150 \mathrm{ml}$ methacrylate monomer, $25 \mathrm{~g}$ polyethylene glycol distearate (mol wt 1,540, Armour Industrial Chemical Co., Philadelphia, Pa.), $18 \mathrm{ml}$ dibutylphthalate (Polysciences, Inc.), $1.2 \mathrm{~g}$ benzoyl peroxide (Eastman Organic Chemicals Div., Rochester, N. Y.), 50 g methacrylate polymer VS 100 (Rohm and Haas Co., Philadelphia, Pa.), 8 drops Igepol 631 (wetting agent) (Chemical Sales Co., Denver, Colo.).
The incubation medium (9) was prepared by diazotizing 4 drops of $4 \%$ pararosaniline (Sigma Chemical Co., St. Louis, Mo.) in $2 \mathrm{~N} \mathrm{HCl}$ with 4 drops of $4 \% \mathrm{NaNO}_{2}$ in distilled water to which had been added $60 \mathrm{ml}$ of $0.1 \mathrm{M}$ Michaelis buffer and $25 \mathrm{mg}$ naphthol-ASD chloroacetate (Sigma Chemical Co., St. Louis, Mo.) dissolved in $1 \mathrm{ml}$ dimethylformamide (final $\mathrm{pH}: 6.3$ ), The sections were then rinsed in tap water and counterstained with $1 \%$ toluidine blue for $15 \mathrm{~min}$. After removal of excess toluidine blue and dehydration in 95 and $99 \%$ isopropanol, the sections were cleared in xylene, and a cover slip was applied over a drop of immersion oil.

All cells of the erythrocytic and neutrophilic series containing recognizable nuclear material were counted in duplicate sections. Neutrophil forms, including promyelocytes, were easily recognizable by the presence of esterase-positive granules. All morphologically recognizable neutrophilic forms were esterase positive. Only a rare basophil reacted. Canine monocytes, lymphocytes, plasma cells, and eosinophils did not stain in the naphthol-ASD-chloroacetateesterase reaction. The neutrophil series was classified into three categories according to the following nuclear characteristics: (a) Promyelocytes and myelocytes had a large, round, oval or minimally indented nucleus with a fine chromatin pattern with or without nucleoli. (b) Metamyelocytes and band forms had elongated nuclei with coarse chromatin patterns and no nucleoli. (c) Segmented neutrophils demonstrated clumped chromatin and at least one filament between lobes (a filament was defined as a constriction of nuclear material to less than $\frac{1}{5}$ the diameter of the adjacent lobe). Cell profiles that did not reveal the entire nuclear contour could usually be classified on the basis of the outlined criteria. Those cells which fell between two classes were put into the more mature class. Autoradiographs of marrow biopsies obtained within 30 -min of pulse labeling with $\left[{ }^{3} \mathrm{H}\right]$ thymidine showed no grains in metamyelocytes or band forms.

Since individual neutrophilic or nucleated erythroid cells appeared in several adjacent sections, direct cell counts overestimated the actual cell number by a factor related to cell diameter and section thickness (3). The empirical "multiple counting factor" was determined for at least 50 cells of each morphologic type in five different animals by determining the number of serial sections that showed identifiable nucleated profiles of the same cell. Specific cells were identified in enlarged photographs of sequential sections by their relationship to marrow structures such as vessels, fat spaces, bony spicules, megakaryocytes, etc. Correction for size was then made by dividing the raw cell count on the section by the multiple counting factor.

To determine total marrow cellularity, the specific activity of normoblasts in individual sections was related to the total skeletal activity $(3,4)$. Radioactivity in marrow sections was counted in a low background gas flow beta counter (Lowbeta Counter, Beckman Instruments, Inc., Fullerton, Calif.) to a statistical error of less than 3\%. Background counts were below $1 \mathrm{cpm}$ and net activity in the sections ranged between 12 and $30 \mathrm{cpm}$. The elution of ${ }^{50} \mathrm{Fe}$ from the marrow during processing was $0.43 \% \pm 0.08$ (1 SD). The specific activity per normoblast was determined in a section from its radioactivity and the number of normoblasts corrected for multiple counting error. Total marrow activity was determined by counting the entire skeleton, isolated from the autoclaved carcass, and an appropriate standard at a fixed distance from a sodium iodide crystal detector. In evaluating counting error, the coefficient of variation was determined by the method of Copeland (10). 


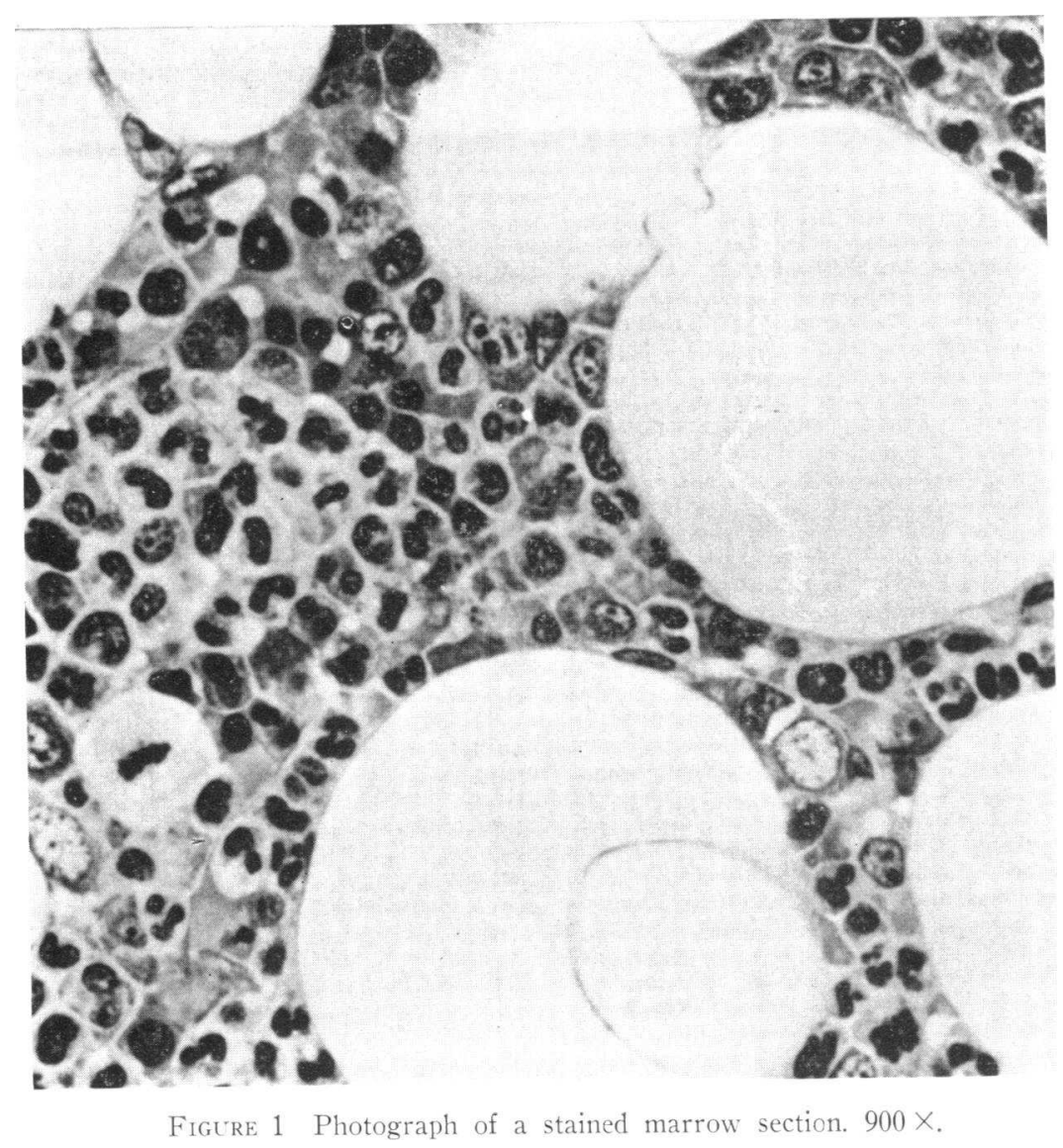

The accuracy of tissue-section measurements of marrow cellularity was assessed in six dogs by comparing the difference in the results obtained before and after leukopheresis with the results of counting of cells actually removed. Under general anesthesia an arteriovenous shunt of silastic tubing (Dow Corning Corporation, Midland, Mich., 0.104 inch internal diameter) was inserted between the carotid artery and the jugular vein. A few centimeters distal from the insertion site, the shunt was fixed to the skin at the site of exit by placing several anchoring sutures through a Dacron felt cuff. Under optimum conditions these shunts remained patent for several weeks. $1 \mathrm{wk}$ after surgery at a time when there was no evidence of local inflammation, base-line values of the number of marrow nucleated red cells and marrow neutrophils were obtained. The number of postmitotic marrow neutrophils (PMN) was determined from the EIT which established the number of nucleated red blood cells (NRBC) and the N/E ratio of marrow sections according to the following formulae:

$$
\mathrm{NRBC}\left(\text { cells } \times 10^{9} / \mathrm{kg}\right)=\mathrm{EIT} \times \frac{\mathbf{5 . 4 8}}{0.90}
$$

where 5.48 represents the mean normal NRBC mass $\left(\times 10^{\circ}\right)$ $\mathrm{kg}),{ }^{4} 0.90$ the mean normal EIT $(\mathrm{mg} \mathrm{Fe} / 100 \mathrm{ml}$ whole

4 Since the EIT values of 40 normal animal studies during the course of these and other studies have demonstrated the normal frequency distribution, the arithmetic mean appears an appropriate expression.

blood/day)

$$
\operatorname{PMN}\left(\text { cells } \times 10^{9} / \mathrm{kg}\right)=\mathrm{NRBC} \times \text { ratio } \frac{\mathrm{PMN}}{\mathrm{E}}
$$

where $\mathrm{PMN} / \mathrm{E}$ represents the ratio of $\mathrm{PMN}$ to nucleated erythroid cells. $16 \mathrm{~h}$ after the initial PIT and bone marrow biopsy and $8 \mathrm{~h}$ before leukopheresis, Depo-Medrol (Upjohn Co., Kalamazoo, Mich.), $10 \mathrm{mg} / \mathrm{kg}$, was injected intramuscularly to raise the circulating neutrophil count and thereby increase the efficiency of leukocyte removal. The unanesthetized animal was then leukopheresed over an 8-h period by exchanging half of his blood volume at $30-\mathrm{min}$ intervals. Blood was collected into plastic bags (TA-5 Transfer Packs, Fenwal Laboratories, Inc., Morton Grove, Ill.) containing acid citrate dextrose (ACD) with a final concentration of $0.15 \mathrm{ml} / \mathrm{ml}$ whole blood. The bags were centrifuged at $450 \mathrm{~g}$ for $15 \mathrm{~min}$. By using a Fenwal plasma extractor, platelet-rich plasma was expelled into another bag. The buffy coat layer was clamped off, removed, and pooled. The plasma and red cells were then recombined and injected through the venous side of the shunt over a 10 -min period. $1 \mathrm{ml}$ of $10 \%$ calcium-gluconate $/ 100 \mathrm{ml}$ blood was given with each reinfusion. Red cell losses associated with the removal of the buffy coat were compensated as accurately as possible by supplying homologous ACD anti-coagulated whole blood drawn from an unmatched donor 2 days before leukopheresis in an amount equal to that of the red cells lost. The use of homologous blood in these studies was considered appropriate since it had produced no 
TABLE I

Counting Variability

\begin{tabular}{ccccc}
\hline & & \multicolumn{3}{c}{ Coefficient of variation } \\
\cline { 3 - 5 } $\begin{array}{c}\text { Cells } \\
\text { counted }\end{array}$ & $\begin{array}{c}\text { Number } \\
\text { of obser- } \\
\text { vations }\end{array}$ & $\begin{array}{c}\text { Promyelo- } \\
\text { cytes and } \\
\text { myelocytes* }\end{array}$ & $\begin{array}{c}\text { Metamyelo- } \\
\text { cytes and } \\
\text { band forms* }\end{array}$ & $\begin{array}{c}\text { Segmented } \\
\text { neutrophils* }\end{array}$ \\
\hline 2,500 & 20 & 10.7 & 15.3 & 14.6 \\
5,000 & 10 & 6.5 & 11.2 & 12.7 \\
10,000 & 5 & 3.1 & 9.6 & 9.7 \\
\hline
\end{tabular}

* Ratio to erythroid cells.

effect on blood neutrophil distribution or turnover in other studies (11). Over an 8-h period, a total of 16 exchanges were performed at 30 -min intervals. Total granulocyte removal during leukopheresis was determined from the volume of the buffy coat pool and its neutrophil concentration. White cell counts were done with an electronic particle counter (Coulter Electronic Counter model B, Hialeah, Fla.) using cetrimide solution (12) for dilution and red cell lysis. At the end of leukopheresis, a second bone marrow biopsy was obtained to determine the marrow deficit as compared with the initial biopsy. This figure, plus the calculated loss of circulating neutrophils, was used to estimate the total number of leukocytes removed by leukopheresis. The size of the intravascular granulocyte pool was determined by multiplying the circulating neutrophil count by an assumed blood volume of $74 \mathrm{ml} / \mathrm{kg}$ (13) and also by assuming that the circulating neutrophils represented $65 \%$ of the neutrophils within the vascular system (11).

\section{RESULTS}

In sections of marrow biopsies prepared as described, both erythroid and neutrophil elements were easily recognized (Fig. 1). Beginning with promyelocytes, all neutrophils were clearly identified by their esterasepositive primary granules. Maturation stages were determined by their nuclear configuration. While megakaryocytes and red cell precursors appeared randomly distributed in the sections, promyelocytes and myelocytes showed some selective positioning along trabeculae

TABLE II

Distribution of Marrow Neutrophilic Cells

\begin{tabular}{lccc}
\hline & \multicolumn{3}{c}{ Ratio* } \\
\cline { 2 - 4 } & $\begin{array}{c}\text { Promyelo- } \\
\text { cytes and } \\
\text { myelocytes }\end{array}$ & $\begin{array}{c}\text { Metamyelo- } \\
\text { cytes and } \\
\text { band forms }\end{array}$ & $\begin{array}{c}\text { Segmented } \\
\text { neutrophils }\end{array}$ \\
\hline Rib & 0.202 & 0.262 & 0.396 \\
Vertebra & 0.206 & 0.241 & 0.379 \\
Right pelvis & 0.191 & 0.261 & 0.386 \\
Left pelvis & 0.197 & 0.247 & 0.348 \\
Mean & 0.199 & 0.253 & 0.377 \\
Standard deviation & 0.007 & 0.001 & 0.021 \\
Coefficient of variation & $3.3 \%$ & $4.1 \%$ & $5.5 \%$ \\
\hline
\end{tabular}

* Ratio of designated neutrophil class to erythroid cells, corrected for multiple counting. and arterioles. To assess counting variability, $5 \times 10^{4}$ neutrophilic and erythroid forms were counted in one biopsy and $\mathrm{N} / \mathrm{E}$ ratios established. A coefficient of variation below $10 \%$ was achieved only after a total of $10^{4}$ cells had been counted (Table I).

Variations in N/E ratios were examined independently in 20 duplicate counts of $10^{4}$ cells. A coefficient of variation of $7.3 \%$ was observed in the ratio between mitotic cells (promyelocytes and myelocytes) and normoblasts. The variation in the ratio between metamyelocyte and band neutrophils and between segmented neutrophils vs. normoblasts was $7.8 \%$. The consistency of these ratios throughout the skeleton was determined on duplicate counts of 10,000 cells in sections made from various biopsy sites shown in Table II. The ratios obtained from rib, vertebra, and pelvic marrow did not vary significantly.

While these ratios were suitable for assessing variation, a correction for multiple counting error was required to determine the actual numer of erythroid and neutrophilic cells. In the red cell series the average number of serial sections containing identifiable portions of a single cell was 3.15 for pronormoblasts, 2.56 for intermediate normoblasts, and 1.74 for late normoblasts (Table III). The proportion of these three stages of red cell development among a thousand NRBC in each of five normal dogs was found to be $3.28 \% \pm 0.81$, $17.46 \% \pm 2.10$, and $79.26 \% \pm 1.60$. The composite multiple counting error for normoblasts, taking into account both multiple counting and frequency of cell type $(3.15 \times 3.28+2.56 \times 17.46+1.74 \times 79.26 / 100) \quad$ was 1.93. The correction for myelocytes was 2.76 , for metamyelocytes and bands 2.11, and for segmented neutrophils 2.07 (Table III). By using the composite factor for NRBC and the multiple counting factor for each stage of granulocyte development, true ratios between two cell species were calculated (Table IV). In the same table are shown the $\mathrm{N} / \mathrm{E}$ ratios obtained from

TABLE III

Correction Factor for Multiple Counting

\begin{tabular}{lcc}
\hline \multicolumn{1}{c}{ Cell type } & $\begin{array}{c}\text { No. of cells } \\
\text { examined }\end{array}$ & $\begin{array}{c}\text { Correction } \\
\text { factor* }\end{array}$ \\
\hline Promyelocytes and myelocytes & 58 & $2.76 \pm 0.15$ \\
Metamyelocytes and band forms & 53 & $2.11 \pm 0.16$ \\
Segmented neutrophils & 60 & $2.07 \pm 0.07$ \\
& 51 & $3.15 \pm 0.17$ \\
Proerythroblasts & 55 & $2.56 \pm 0.08$ \\
Intermediate erythroblasts & 65 & $1.74 \pm 0.06$ \\
Late erythroblasts & & \\
\hline
\end{tabular}

* Mean $\pm 1 \mathrm{SD}$ of five biopsies of five different animals representing the number of marrow sections spanned by each cell type. 
TABLE IV

$N / E$ Ratios

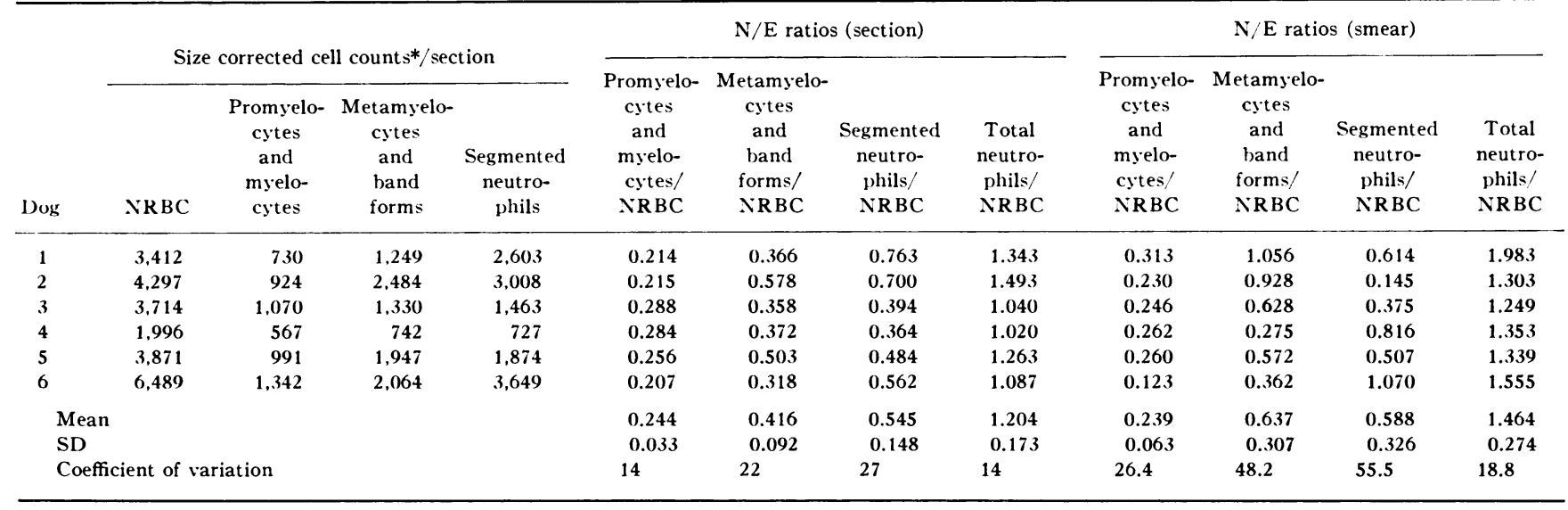

* Mean counts of duplicate sections were corrected for multiple counting error. For example, in dog 1 metamyelocytes and bands counted were 2,630 ; factor for multiple counting was 2.11 ; size corrected number of metamyelocytes and bands was 1,249.

differential counts of 5,000 cells on marrow smears in the same dog. The ratios obtained by counting cells in smears were slightly higher than those obtained from the sections, with about a twofold greater variation.

Absolute cellularity was determined by relating the specific activity of erythroid cells in duplicate counted sections of iliac marrow (corrected for multiple counting) with the total activity of the skeleton (Table V). The only assumption in this calculation is a marrow distribution of radioiron proportionate to its erythroid cellularity. The EIT was also related to the NRBC mass. The mean normoblast population of six dogs was $5.48 \pm 0.78 \times 10^{\circ} / \mathrm{kg}$, corresponding to a mean EIT of $0.90 \pm 0.11 \mathrm{mg} \mathrm{Fe} / 100 \mathrm{ml}$ whole blood/day.

The total number of neutrophils was calculated directly by using radioiron to determine the relation between the number of cells counted in the marrow section and the number of cells in the total skeleton (Table VIA). Mean values expressed as cells $\times 10^{\circ} / \mathrm{kg}$ were $1.36 \pm 0.37$ promyelocytes and myelocytes, $2.25 \pm$ 0.30 metamyelocytes and band forms, and $2.95 \pm 0.70$ segmented neutrophils. The total number of neutrophilic

TABLE V

NRBC Mass and EIT

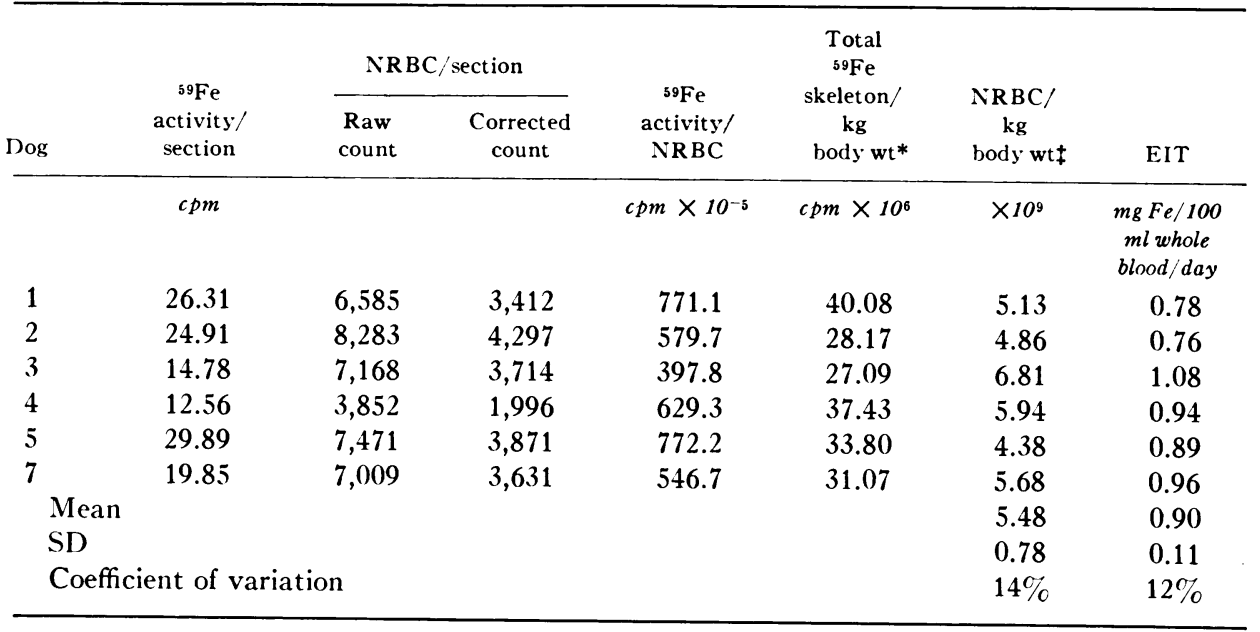

${ }^{*}$ Derived from ${ }^{59} \mathrm{Fe}$ activity in the total skeleton divided by the total weight of the animal in kilograms.

$\ddagger$ Derived by dividing total skeletal ${ }^{59} \mathrm{Fe}$ activity by ${ }^{59} \mathrm{Fe}$ activity/erythroblast in the marrow section. 
TABLE VI

Number of Marrow Neutrophils

\begin{tabular}{|c|c|c|c|c|c|c|c|c|}
\hline \multirow[b]{2}{*}{ Dog } & \multicolumn{4}{|c|}{$\begin{array}{l}\text { A. Direct calculation } \\
\text { Neutrophils* }\end{array}$} & \multicolumn{4}{|c|}{$\begin{array}{l}\text { B. Calculated through erythroid cells } \\
\text { Neutrophils } \ddagger\end{array}$} \\
\hline & $\begin{array}{l}\text { Promyelo- } \\
\text { cytes } \\
\text { and } \\
\text { myelocytes }\end{array}$ & $\begin{array}{l}\text { Metamyelo- } \\
\text { cytes } \\
\text { and } \\
\text { band forms }\end{array}$ & Segmented & $\begin{array}{c}\text { Total } \\
\text { neutrophils }\end{array}$ & $\begin{array}{l}\text { Promyelo- } \\
\text { cytes } \\
\text { and } \\
\text { myelocytes }\end{array}$ & $\begin{array}{l}\text { Metamyelo- } \\
\text { cytes } \\
\text { and } \\
\text { band forms }\end{array}$ & Segmented & $\begin{array}{c}\text { Total } \\
\text { neutrophils }\end{array}$ \\
\hline & \multicolumn{4}{|c|}{ cells $\times 10^{9} / \mathrm{kg}$} & \multicolumn{4}{|c|}{ cells $\times 10^{9} / \mathrm{kg}$} \\
\hline 1 & 1.11 & 1.90 & 3.90 & 6.91 & 1.08 & 1.86 & 3.87 & 6.81 \\
\hline 2 & 1.04 & 2.81 & 3.40 & 7.25 & 1.07 & 2.83 & 3.44 & 7.34 \\
\hline 3 & 1.96 & 2.44 & 2.68 & 7.08 & 1.95 & 2.42 & 2.67 & 7.04 \\
\hline 4 & 1.69 & 2.21 & 2.17 & 6.07 & 1.69 & 2.21 & 2.17 & 6.07 \\
\hline 5 & 1.12 & 2.20 & 2.12 & 5.44 & 1.15 & 2.25 & 2.17 & 5.57 \\
\hline 6 & 1.28 & 1.97 & 3.48 & 6.73 & 1.28 & 1.97 & 3.47 & 6.72 \\
\hline Mean & 1.36 & 2.25 & 2.95 & 6.58 & 1.37 & 2.26 & 2.97 & 6.59 \\
\hline SD & 0.37 & 0.30 & 0.70 & 0.67 & 0.33 & 0.32 & 0.66 & 0.65 \\
\hline
\end{tabular}

* Calculated from the neutropils in each section times the total skeletal activity divided by the radioactivity in the section.

$\ddagger$ Calculated from the erythroid number and the $\mathrm{N} / \mathrm{E}$ ratio.

forms was $6.58 \pm 0.67 \times 10^{\circ}$ cells $/ \mathrm{kg}$. Similar values were calculated when the number of NRBC was determined by isotope dilution and the neutrophilic number derived from the $\mathrm{N} / \mathrm{E}$ ratio (Table VIB). The relationship between the EIT and the number of NRBC was also examined. The NRBC number determined by isotope dilution (Table VIB) compared to the EIT gave a regression equation of $y=5.60 x+0.43$ with a correlation coefficient of 0.78 .

This method of marrow quantitation was used to evaluate the marrow neutrophil depletion in six dogs leukopheresed over a period of $8 \mathrm{~h}$. Table VII shows data on the postmitotic and circulating neutrophil pools before and after leukopheresis. A mean of $33 \times 10^{\circ}$ neutrophils was removed during leukopheresis. The calculated deficit in the marrow postmitotic pool was $22.7 \times 10^{\circ}$, and the calculated deficit of blood neutrophils was $10.2 \times 10^{\circ}$. Adding these two calculated figures gave an average total removal of $32.9 \times 10^{\circ}$ neutrophils; while by direct measurement, the figure was $33 \times 10^{\circ}$ cells. Calculations in individual animals showed differences in marrow granulocytes as determined by the two techniques of $5-34 \%$.

\section{DISCUSSION}

Direct quantification of marrow hematopoietic cellularity by isotope dilution depends on accurate measurements of the number and type of cells in the marrow

TABLE VII

Marrow Neutrophil Removal by Leukopheresis

\begin{tabular}{lrrrrrr}
\hline & \multicolumn{5}{c}{ Animals studied } \\
\cline { 2 - 7 } & \multicolumn{1}{c}{1} & \multicolumn{7}{c}{ 2 } & 3 & 4 & 5 & 6 \\
\hline Neutrophils removed by leukopheresis & & & & & & \\
$\quad$ Total cells removed & 41.4 & 27.0 & 37.7 & 39.9 & 30.2 & 21.9 \\
$\quad$ Derived from blood* & 7.5 & 9.3 & 11.6 & 14.6 & 7.8 & 10.2 \\
$\quad$ Derived from marrow & 33.9 & 7.7 & 26.1 & 25.3 & 22.4 & 11.7 \\
Marrow neutrophils by biopsy & & & & & & \\
No. before leukopheresis & 64.9 & 56.0 & 68.4 & 66.3 & 61.7 & 72.7 \\
$\quad$ No. after leukopheresis & 36.7 & 37.5 & 39.9 & 45.8 & 37.1 & 57.0 \\
Marrow deficit & 28.2 & 18.5 & 28.5 & 20.5 & 24.6 & 15.7 \\
\hline
\end{tabular}

* Calculated from the difference in the blood granulocyte pool before and after leukopheresis. Circulating granulocytes were determined by multiplying their concentration by 74 (estimated blood volume) times kilograms of body weight times 100/65 (allowance for contribution of the marginal pool). 
sample and precise determination of the relation between total marrow and marrow sample. It is questionable whether cell suspensions prepared for this purpose are ever representative. Histologic examination of a biopsy made after aspiration of hematopoietic cells from that area discloses a number of residual cells. Furthermore, the process of aspirating ruptures cells. In one early study approximately one-third of the hemoglobin was shown to be lost from the marrow normoblasts (4). Considerable sampling variability is found in myeloid-erythroid (M/E) ratios reported in dogs by different investigators. Stasney and Higgins reported a mean $\mathrm{M} / \mathrm{E}$ ratio of 0.53 in animals which had been subjected to other experimental procedures (14). Rekers and Coulter (2) and Thomas, Plain, and Thomas (15) found an average granulocyte-erythroid $(\mathrm{G} / \mathrm{E})$ ratio of 1.9. Our own results from cell suspensions gave an $\mathrm{N} / \mathrm{E}$ ratio of 1.4 , and from marrow sections, an $\mathrm{N} / \mathrm{E}$ ratio of 1.2 .

In this study it was possible to obtain and process marrow biopsies in which virtually all cells were intact and recognizable. Further requisites for accurate data include counting a significant number of cells to minimize distributional variation and making proper corrections for cell size, i.e., counting a cell only once when it is represented in multiple sections. The coefficient of variation of $\mathrm{N} / \mathrm{E}$ ratios calculated from 10,000 cells in sections was less than $10 \%$. The size correction factor derived in these studies has been discussed elsewhere in reference to megakaryocyte quantitation (3) and depends on the uniformity of section thickness. In the present study differences in section thickness were monitored by radioactive labeling of the tissue, and the mean variation of sections was found to be $\pm 8.7 \%$ (including counting error). The distribution of erythroid and neutrophilic cells was found to be constant in different parts of the skeleton (Table II), as has been reported by others $(2,3)$.

Various approaches have been used in the dog to quantify hematopoietic tissue. One approach is to put together relevant data reported by separate investigators. For example, Fairman and Whipple estimated the total intramedullary volume to be about $20 \mathrm{ml} / \mathrm{kg}$ (1), while Rekers and Coulter (2) found approximately $10^{\circ}$ cells $/ \mathrm{ml}$ of red cell marrow. If one were to assume that active marrow represents $20-80 \%$ of the medullary cavity (1) and that the white cell precursors in the narrow outnumber the erythroid cells by a $2: 1$ ratio (2), then the calculated numbers of red cell and white cell precursors would be about $1.5-5 \times 10^{\circ} / \mathrm{kg}$ and $3-$ $10 \times 10^{\circ} / \mathrm{kg}$, respectively. Considerably higher figures of $10.3 \times 10^{\circ} / \mathrm{kg} \mathrm{NRBC}$ and $12.9 \times 10^{\circ}$ myeloid cells were reported by Alexanian, McAlexander, and Donohue (16) employing cell suspension counts and radio- active iron determination of total marrow. Their values were influenced by an allowance for cell breakage which nearly doubled the actual counts obtained. We do not believe this correction was justifiable since at least a portion of the breakage represents cytoplasmic stripping, leaving countable nuclei.

A number of estimates have been made on the basis of kinetic studies (17-19). Boggs, Athens, Cartwright, and Wintrobe (17) calculated a marrow pool of 14.4 $\times 10^{9}$ postmitotic neutrophils $/ \mathrm{kg}$ on the basis of tritium-labeled thymidine measurements of marrow transit time and calculations of circulating granulocyte turnover based on $\left[{ }^{32} \mathrm{P}\right]$ diisopropylphosphofluoridate (DF${ }^{32} \mathrm{P}$ ) tagging (18). However, a recent study indicates that measurements of circulating leukocyte turnover with $\mathrm{DF}^{32} \mathrm{P}$ give falsely high values because this radioactive tag is partially eluted from the cells (11).

Kinetic measurements of mobilizable granulocytes made by Thomas et al. (15) are in reasonable agreement with the present study. They established a vascular connection between the blood of normal animals with that of animals made neutropenic by radiation. In $6 \mathrm{~h}, 6.7$ and $8.5 \times 10^{\circ}$ neutrophils were removed from the two normal animals to neutropenic recipients. By making allowances for granulocytes delivered from circulating pool $\left(0.7 \times 10^{\circ}\right)$ and those entering the storage pool from precursors during the 6-h period $\left(0.4 \times 10^{9}\right)$ the postmitotic marrow pool in their studies might be estimated to be approximately $6.6 \times 10^{\circ}$ cells.

To assess the accuracy of the method described in this paper, a rapid change in the marrow neutrophils was accomplished by leukopheresis with removal of about a third of the postmitotic granulocyte pool. The average calculated change in blood and marrow of six animals was virtually identical to that determined by direct counting of the cells removed. Such close agreement was probably fortuitous since several assumptions are involved in the calculations, such as a constant ratio between marginal and circulating neutrophils and a steady input into the nonmitotable pool from the mitosing marrow. The agreement does suggest that no significant systematic error is involved in the calculation of marrow cellularity. In the individual animal an average divergence of $15 \%$ was found between the calculation based on blood cell changes and cells removed as compared to the calculation based on changes in marrow cellularity (Table VII). Furthermore, the rapid mobilization of the storage neutrophils into the blood by leukopheresis indicates regulatory mechanism(s) controlling this compartment independent of neutrophil production. These studies provide the basis for both experimental and clinical investigations of neutrophil kinetics and its regulation. 


\section{ACKNOWLEDGMENTS}

We gratefully acknowledge the technical assistance of Loretta Willis and Jean Greenaway, and the assistance of Dr. Eloise Giblett in reviewing the manuscript.

This work was supported by research grants (HL06242 and HL-11775) and a training grant (AM-05130) from the National Institutes of Health and by the Washington State Heart Association.

\section{REFERENCES}

1. Fairman, E., and G. H. Whipple. 1933. Bone marrow volume in adult dogs. Am. J. Physiol. 104: 352-355.

2. Rekers, P. E., and M. Coulter. 1948. A hematological and histological study of the bone marrow and peripheral blood of the adult dog. Am. J. Med. Sci. 216: 643655.

3. Harker, L. A. 1968. Megakaryocyte quantitation. $J$. Clin. Invest. 47 : 452-457.

4. Donohue, D. M., B. W. Gabrio, and C. A. Finch. 1958. Quantitative measurement of hematopoietic cells of the marrow. J. Clin. Invest. 37: 1564-1570.

5. Finch, C. A., K. Deubelbeiss, J. D. Cook, J. W. Eschbach, L. A. Harker, D. D. Funk, G. Marsaglia, R. S. Hillman, S. Slichter, J. W. Adamson, A. Ganzoni, and E. R. Giblett. 1970. Ferrokinetics in man. Medicine (Baltimore). $49: 17-53$.

6. Cook, J. D., G. Marsaglia, J. W. Eschbach, D. D. Funk, and C. A. Finch. 1970. Ferrokinetics: a biologic model for plasma iron exchange in man. J. Clin. Invest. 49: 197-205.

7. Holt, S. J., E. E. Hobbiger, and G. L. S. Pawan. 1960. Preservation of integrity of rat tissues for cytochemical staining purposes. J. Biophys. Biochem. Cytol. 7: 383-386 + plate 210 .

8. Zambernard, J., M. Block, A. Vatter, and L. Trenner. 1969. An adaptation of methacrylate embedding for routine histopathologic use. Blood J. Hematol. 33: 444-451.
9. Leder, L. D. 1964. Über die selektive fermentcytochemische Darstellung von neutrophilen myeloischen Zellen und Gewebs-mastzellen im Paraffinschnitt. Klin. Wochenschr. $42: 553$.

10. Copeland, B. E. 1957. Standard deviation. A practical means for the measurement and control of the precision of clinical laboratory determinations. Am. J. Clin. Pathol. 27 : 551-558.

11. Deubelbeiss, K. A., J. T. Dancey, L. A. Harker, and C. A. Finch. 1975. Neutrophil kinetics in the dog. $J$. Clin. Invest. 55: 833-839.

12. Cartwright, G. E. 1968. Diagnostic Laboratory Hematology. Grune \& Stratton, New York. 4th edition. 67.

13. Rapaport, E., H. Kuida, F. W. Haynes, and L. Dexter. 1956. Pulmonary red cell and plasma volumes and pulmonary hematocrit in the normal dog. Am. J. Physiol. $185: 127-132$.

14. Stasney, J., and G. M. Higgins. 1937. A quantitative cytologic study of the bone marrow of the adult dog. Am. J. Med. Sci. 193: 462-470.

15. Thomas, E. D., G. L. Plain, and D. Thomas. 1965. Leukocyte kinetics in the dog studied by cross circulation. J. Lab. Clin. Med. 66: 64-74.

16. Alexanian, R., R. McAlexander, and D. Donohue. 1965. Effect of splenectomy upon bone marrow cellularity in the dog. Clin. Res. 13: 38. (Abstr.)

17. Boggs, D. R., J. W. Athens, G. E. Cartwright, and M. M. Wintrobe. 1965. Leukokinetic studies. IX. Experimental evaluation of a model of granulopoiesis. J. Clin. Invest. 44 : 643-656.

18. Raab, S. O., J. W. Athens, O. P. Haab, D. R. Boggs, H. Ashenbrucker, G. E. Cartwright, and M. M. Wintrobe. 1964. Granulokinetics in normal dogs. Am. J. Physiol. 206: 83-88.

19. Maloney, M. A., and H. M. Patt. 1968. Granulocyte transit from bone marrow to blood. Blood J. Hematol. 31 : 195-201. 